\title{
Morphogenesis, volume and number of hop (Humulus lupulus L.) glandular trichomes, and their influence on alpha-acid accumulation in fresh bracts of hop cones
}

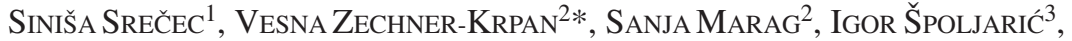 \\ IVKA KVATERNJAK ${ }^{1}$, GORDAN MRŠIĆ ${ }^{3}$ \\ ${ }^{1}$ Križevci College of Agriculture, M. Demerca 1, HR-48260 Križevci, Croatia \\ ${ }^{2}$ Faculty of Food Technology and Biotechnology, University of Zagreb, Department \\ of Biochemical Engineering, Pierrotijeva 6, HR-10000 Zagreb, Croatia \\ ${ }^{3}$ Forensic Science Centre »Ivan Vučetić«, Ilica 335, HR-10000 Zagreb, Croatia \\ The ESEM investigations revealed the morphogenesis of peltate glandular trichomes, \\ which was divided into five phases. In phase one, new peltate glandular trichomes were \\ initiated; in phase two, they were differentiated; in phase three trichomes grew vigor- \\ ously; in phase four they were determined; in the fifth and final phase they came to maturity. \\ Volume of glandular trichome during the different phases of morphogenesis varied from \\ $0.25 \times 10^{-2} \mathrm{~mm}^{3}$ in phase 1 , to $1.95 \times 10^{-2} \mathrm{~mm}^{3}$ in phase 5 . More glandular trichomes are \\ placed on the base of the adaxial side of bracts (average $7 \mathrm{~mm}^{-2}$ ) than on the base of \\ abaxial side (average $5.8 \mathrm{~mm}^{-2}$ ). In this research, positive Spearman's rank order correla- \\ tions were found between the average number of glandular trichomes and content of $\alpha$-acids \\ as well as between the average volume of glandular trichomes and content of $\alpha$-acids.
}

Key words: Humulus lupulus, trichome, morphogenesis, ESEM, alpha-acid

\section{Introduction}

Peltate glandular trichomes are micro bodies of spheroid and spherical shape on the epidermis of hop cone bracts in which the hop metabolites are accumulating (OLIVEIRA and PAIS 1988, 1990; ČEH et al. 2007; WANG et al. 2008). Seven morphological development stages of peltate glandular trichomes are described and the relation between their morphogenesis and accumulation of secondary metabolites was clarified (SAITO et al. 1995, Hirosawa et al. (1995). Kim and MAhlberg (2000) described the early development of the secretory cavity of chemically fixed peltate glands in hop. The same authors found light and gray secretions on the irregular inner surface of the cuticle. Moreover, they described

\footnotetext{
* Corresponding author, e-mail: vzkrpan@pbf.hr

Copyright $^{\circledR} 2011$ by Acta Botanica Croatica, the Faculty of Science, University of Zagreb. All rights reserved.
} 
how secretions contributed to the thickening of the cuticle and created a network of striae distributed throughout the cuticle. The development of lupulin glands is strictly divided into a growth phase and biosynthetic-secretory phase (SugIYAma et al. 2006). Activity of VPS gene (valerophenone synthase), which is involved in the first steps of bitter resin ( $\alpha$-acid) biosynthesis, was strong when the cuticle was slightly detached from the glandular head cells. WANG et al. (2008) described three biosynthetic pathways for terpene-derived natural products found in hop trichomes and activity of VPS gene is obvious in C pathway of terpene-derived natural products. The final step of carbon pathway is the biosynthesis of humulone or $\alpha$-acids.

The primarily goal of this research was to define the stages of peltate glandular trichome morphogenesis and also to consider the changes in their volume and morphology during the most important phases. The secondary goal was to define the influence of peltate glandular trichome number and volume on level of $\alpha$-acids, the most important chemical compound of hops.

\section{Materials and methods}

Hop (Humulus lupulus L. cv. Aurora) grown in the hop garden of the Gregurovec Hop Co-operative near Križevci College of Agriculture was used as experimental material. The hop cones or female inflorescence were successively collected every week during the hop harvest in the phenological phase of technological maturity. From the beginning of technological maturity till the end of hop harvest, five samples of hop cones were selected and treated further as dependent samples. The ESEM observations of peltate glandular trichome morphogenesis and shape were provided on bracts separated from the central string (rachis) of the hop cones. The bracts were of approximately equal length and diameter. The remaining bracts were used for analysis of $\alpha$-acid content.

In ESEM studies, a Philips XL 30 ESEM (detector: Edax, type PV 9760/68 ME, resolution $134.30 \mathrm{eV}$, BSE detector: Philips PW 6848/00) and EDAX Genesis v.5.21 software were used. Photographs were taken at an accelerating voltage of $25 \mathrm{kV}$ under recording time of 5 seconds. Diameter of the observed area was $10 \mathrm{~mm}$.

At the same time the analyses of $\alpha$-acids were also provided using the method of lead conductance value (LCV) of hops, powders and pellets, according to Analytica - European Brewery Convention 7.4 (AnONYMOus 1998). This method was chosen due to following reasons. First, the time for preparation of samples and standard solution of lead acetate is very short. Second, the analyses of $\alpha$-acids were provided from the bracts separated from the same hop cones from which the bracts for ESEM observations were taken (required weight of the hop bract sample for LCV analyses is $5 \mathrm{~g}$ only). Third, the results of the LCV method are comparable with the results of other analytical methods prescribed by the Analytical Committee of European Brewery Convention (ANONYMOUs 2006) including HPLC analysis (FORSTER 1987, 2001; BRIGGS et al. 1981; KoŠIR 1996). Fourth, according to WANG et al. (2008), biosynthesis of humulone or $\alpha$-acids is the final step in the carbon pathway of terpene-derived natural products. For these reasons, use of the LCV method is acceptable for the determination ofthe relationships or possible correlations between the number or volume of glandular trichome (independent variables) and the content of $\alpha$-acids in the same hop cones from which the bracts for ESEM studies were taken. 
Volume of peltate glandular trichomes was calculated by following equation for volume calculation of spheroid bodies:

$$
\mathrm{V}=\frac{4}{3} \pi \cdot a^{2} b
$$

$a=$ width (distance between two points on $\mathrm{x}$-axis in $\mu \mathrm{m}$ )

$b=$ height (distance between two points on y-axis in $\mu \mathrm{m}$ )

The data analyses were provided using the t-test for dependent samples and calculating the least significant differences in order to find significant differences between the number of glandular trichomes on the abaxial and adaxial sides of the bracts and also between the volumes of glandular trichomes in different phases of morphogenesis. Spearman's rank order correlation was also used as nonparametric statistical method (HILL and LEWICKI 2006) for the determination of correlations between dimensions and number of peltate glandular trichomes (independent variables) and level of $\alpha$-acids. Transformation of percents of $\alpha$-acids was done by angular transformation (CHANTER 1975).

During this research a total of 150 ESEM observations of morphology and dimensions of peltate glandular trichome were provided and also 18 chemical analyses of $\alpha$-acid content from six samples of hop cones. Sampling of hop cones was provided every sixth day during the last five weeks of hop vegetation, which corresponded with the phenological phases of hop cone formation and technological maturity.

\section{Results}

After ESEM observations the morphogenesis of peltate glandular trichomes was divided into five phases. The first phase is the initiation of new peltate glandular trichome (Plate 1, Fig. 1, position 1); second phase is the differentiation of the young trichome (Fig. 1, position 2); third phase is intensive growth (Fig. 2); fourth phase is the phase of determination (Fig. 3); the fifth phase is peltate glandular trichome maturity (Fig. 4).

In this research, significant differences were found between the number of glandular trichomes per $\mathrm{mm}^{2}$ on the base and flat areas of the abaxial side of bracts and also on the base area of the adaxial sides of bracts (Tab. 1).

More glandular trichomes are to be found on the bases of the adaxial sides of the bracts (average $7 \mathrm{~mm}^{-2}$ of glandular trichomes) than on the base of the abaxial sides (average 5.8 $\mathrm{mm}^{-2}$ of glandular trichomes) (Tab. 1). The smallest number of glandular trichomes is found on the flat area of the abaxial side of a bract (average $3.12 \mathrm{~mm}^{-2}$ of glandular trichomes).

According to our studies, we assume that the bulbous glandular trichome is just the final stage of peltate glandular trichome development during the phenological phase of hop maturity (Plate 2, Fig. 5).

Average volume of glandular trichome during the different phases of morphogenesis varied from $0.25 \times 10^{-2} \mathrm{~mm}^{3}$ in phase 1 , to $1.95 \times 10^{-2} \mathrm{~mm}^{3}$ in phase 5 (Tab. 2).

In the same observed area peltate glandular trichomes in different phases of morphogenesis (initiation, differentiation, determination, intensive growth and maturity) were found lying next to each other (Plate 2, Fig. 6). 

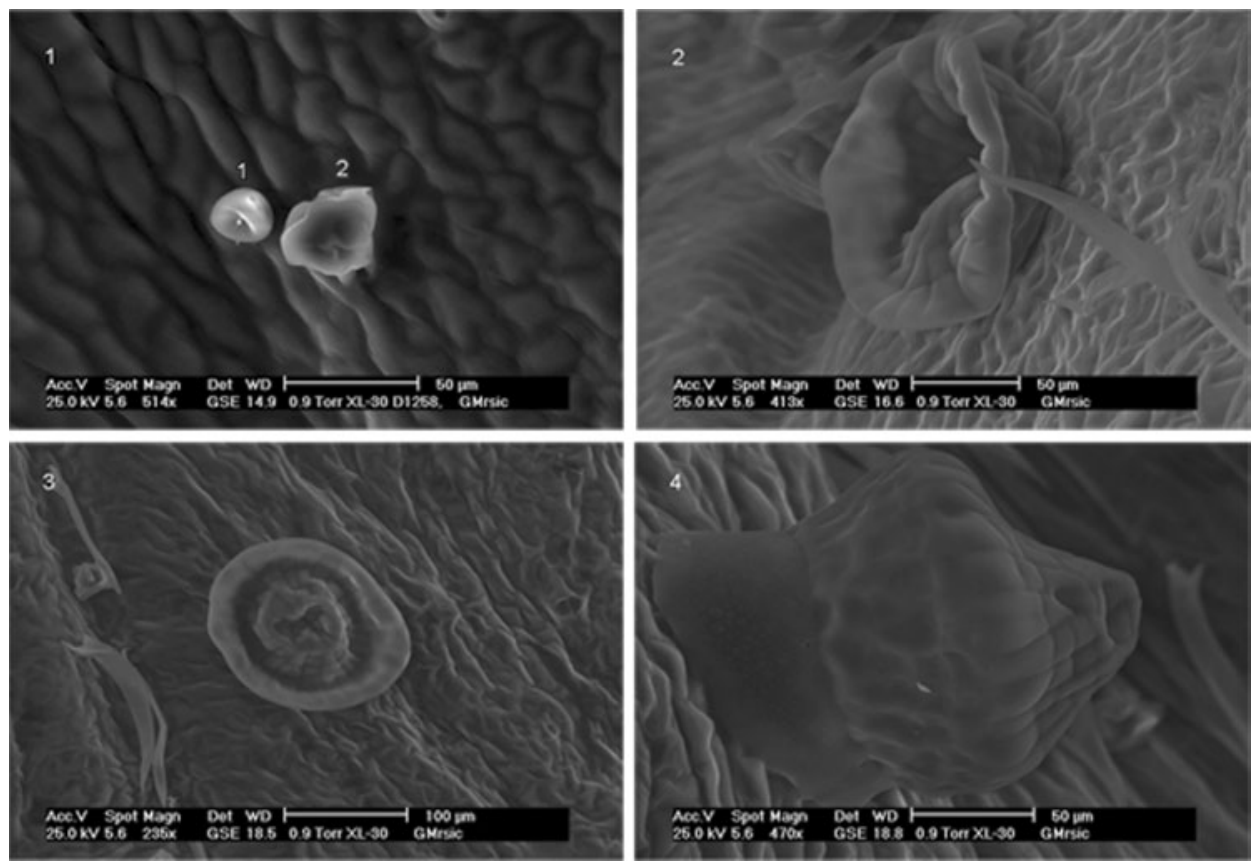

Plate 1. Morphogenesis and differentiation of glandular trichomes. Fig. 1 - first phase of morphogenesis - phase of initiation of young glandular trichome (position 1) and second phase of morphogenesis - phase of differentiation of young glandular trichome (position 2); Fig. 2 third phase of morphogenesis - phase of intensive growth of peltate glandular trichomes; Fig. 3 - fourth phase of morphogenesis - phase of peltate glandular trichome determination; Fig. 4 - fifth phase of morphogenesis - phase of peltate glandular trichome maturity

Tab. 1. Differences between the number of glandular trichomes $\left(\mathrm{mm}^{-2}\right)$ on abaxial and adaxial side of bracts $(\mathrm{N}=121)$

\begin{tabular}{lccc}
\hline $\begin{array}{c}\text { Descriptive } \\
\text { statistics }\end{array}$ & $\begin{array}{c}\text { Flat area of abaxial } \\
\text { side of bracts }\end{array}$ & $\begin{array}{c}\text { Base of abaxial } \\
\text { side of bracts }\end{array}$ & $\begin{array}{c}\text { Base of adaxial } \\
\text { side of bracts }\end{array}$ \\
\hline Mean & 3.12 & 5.83 & 6.95 \\
St. Dev. & 2.02 & 4.32 & 2.62 \\
St. Error & 0.18 & 0.39 & 0.24 \\
Comparisons & Base of abaxial side vs. & Base of adaxial side vs. & Base of adaxial vs. \\
& flat area of abaxial side & flat area of abaxial side & base area of abaxial \\
Diff. of means & $2.71^{* *}$ & $3.82^{* *}$ & side of bracts \\
St. Dev. Diff. & 0.43 & 0.30 & $1.16^{*}$ \\
$\operatorname{LSD}_{(\mathrm{p}=0.05)}$ & 0.84 & 0.58 & 0.45 \\
$\operatorname{LSD}_{(\mathrm{p}=0.01)}$ & 1.11 & 0.77 & 0.88 \\
\hline $\ln$ & & & 1.16 \\
\hline
\end{tabular}

*: $95 \%$ of significance and **: $99 \%$ of significance 

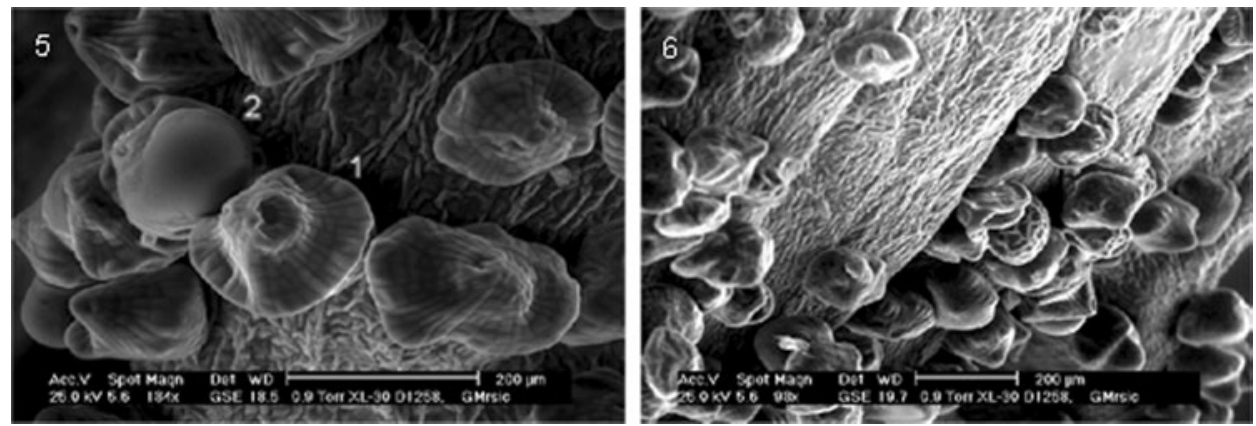

Plate 2. Glandular trichomes, morphogenesis and bulbs. Fig. 5 - peltate glandular trichomes in maturity phase (position 1) and formation of bulbs (position 2); Fig. $\mathbf{6}$ - glandular trichomes in different phases of morphogenesis on same observed area.

Tab. 2. Volume of peltate glandular trichomes $\left(10^{-2} \mathrm{~mm}^{3}\right)$ in different phases of morphogenesis $(\mathrm{N}=36)$

\begin{tabular}{|c|c|c|c|c|c|}
\hline $\begin{array}{c}\text { Descriptive } \\
\text { statistics }\end{array}$ & Phase 1 & Phase 2 & Phase 3 & Phase 4 & Phase 5 \\
\hline Mean & 0.25 & 0.37 & 1.09 & 1.54 & 1.88 \\
\hline St. Dev. & 0.0075 & 0.049 & 0.085 & 0.154 & 0.063 \\
\hline St. Error & 0.0043 & 0.021 & 0.038 & 0.068 & 0.023 \\
\hline Comparisons & $\begin{array}{c}\text { Phase } 2 \text { vs. } \\
\text { Phase } 1\end{array}$ & $\begin{array}{c}\text { Phase } 3 \text { vs. } \\
\text { Phase } 2\end{array}$ & $\begin{array}{c}\text { Phase } 4 \text { vs. } \\
\text { Phase } 3\end{array}$ & $\begin{array}{c}\text { Phase } 5 \text { vs. } \\
\text { Phase } 4\end{array}$ & $\begin{array}{c}\text { Phase } 5 \text { vs } \\
\text { Phase } 3\end{array}$ \\
\hline Diff. of means & $0.12 * *$ & $0.72 * *$ & $0.45^{* *}$ & $0.34 * *$ & $0.79 * *$ \\
\hline St. Dev. Diff. & 0.0015 & 0.016 & 0.025 & 0.027 & 0.013 \\
\hline $\operatorname{LSD}_{(\mathrm{p}=0.01)}$ & 0.004 & 0.04 & 0.068 & 0.001 & 0.036 \\
\hline
\end{tabular}

**: $99 \%$ of significance

In this study strong positive Spearman rank order correlations were found between weeks of hop cone maturity vs. number and volume of glandular trichomes found (Fig. 7).

That phenomenon is also visible on microphotographs of Hirosawa et al. (1995). Positive Spearman rank order correlations were found between the average number of glandular trichomes and the content of $\alpha$-acids (Fig. 8) and also between the average volume of glandular trichomes and the $\alpha$-acid content (Fig. 9).

\section{Discussion}

These results are in line with the results of HiROSAWA et al. (1995) who found increasing values of total $\alpha$-acids from the early A-phase to the late G-phase of peltate glandular trichome development.

According to this study we assume that peltate glandular trichomes after the fifth phase of morphogenesis are transformed into bulb glandular trichomes (Fig. 5). 
SReČEC S., Zechner-KrPan V., Marag S., ŠPOlJarić I., KvaternjaK I., MrŠIĆ G.

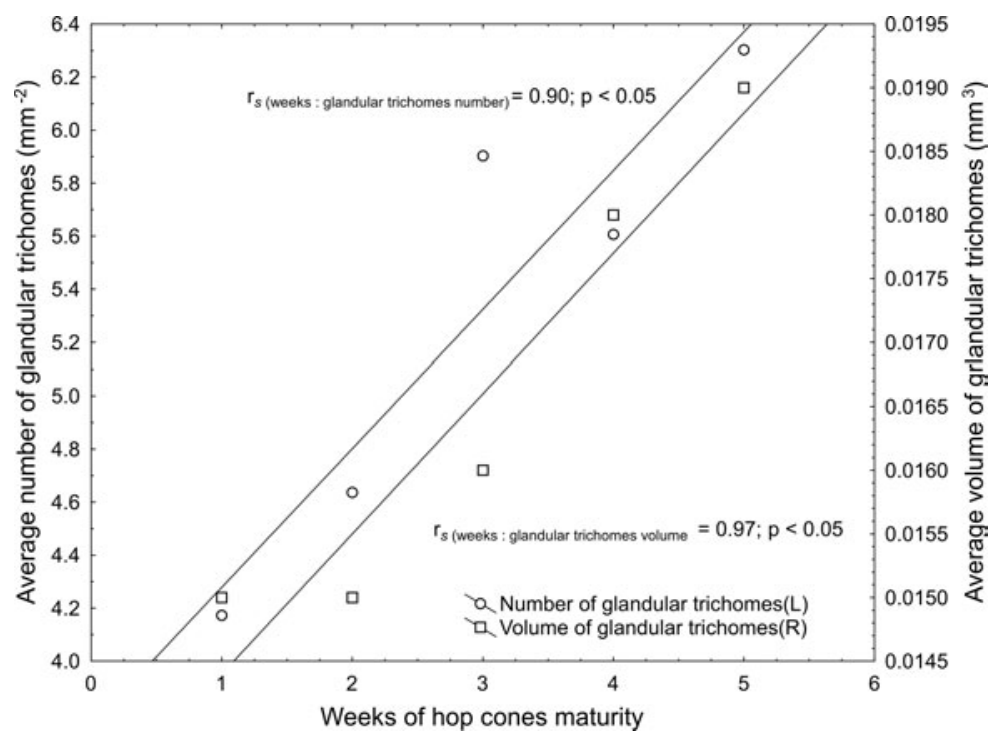

Fig. 7. Spearman rank order correlations between weeks of hop cones maturity during vegetation and hop harvest average number and volume of glandular trichomes

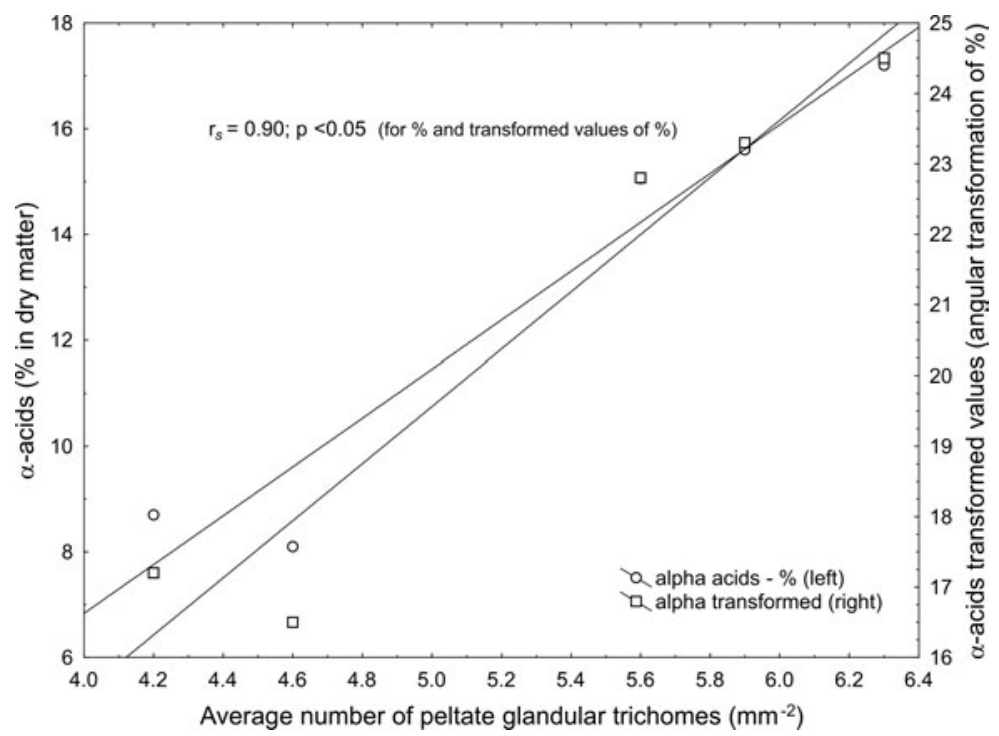

Fig. 8. Spearman's rank order correlations between average number of glandular trichomes and content of $\alpha$-acids

The cause of such a phenomenon could be an increase of the partial pressure of liquids and gasses on the cell walls inside peltate glandular trichomes during the biosynthesis of terpene-derived natural products, particularly $\alpha$-acids which are the final product in the carbon pathway of terpene-derived natural products (WANG et al. 2008). This could be an 


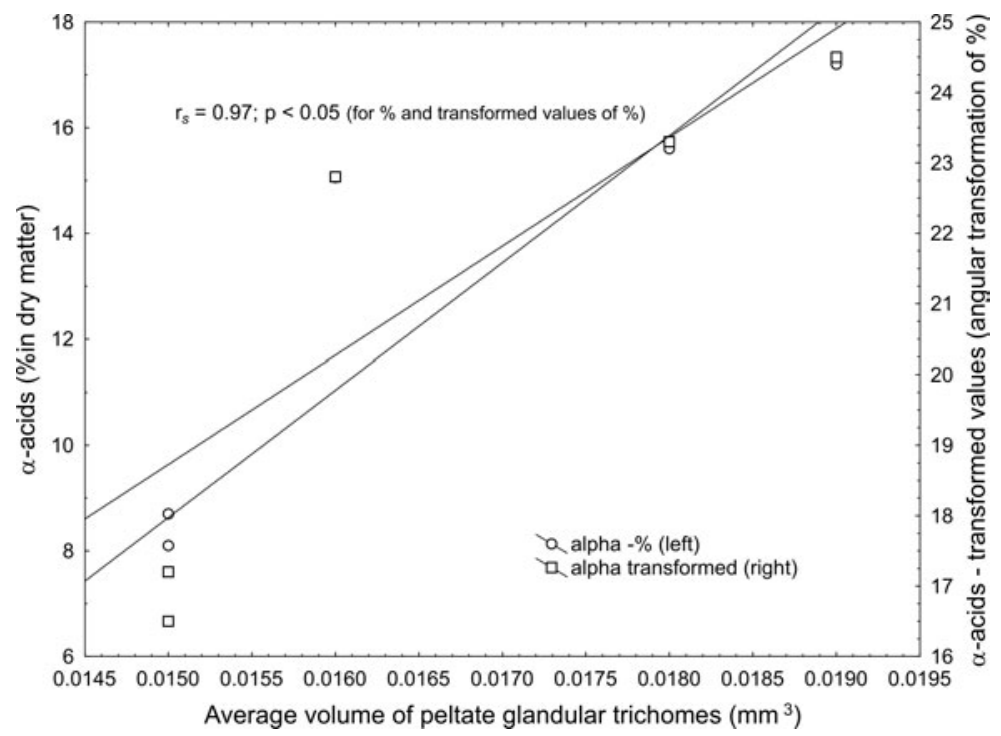

Fig. 9. Spearman's rank order correlations between average volume of glandular trichomes and content of $\alpha$-acids

explanation for the results of OLIVEIRA and PAIS (1988), who found that number of peltate trichomes decreases with the expansion of the leaves (bracts). However, accumulation of hop polyphenols, xanthohmol (ČEH et al. 2007) and finally humulone or $\alpha$-acids (SREČEC et al. 2008, MOZNY et al. 2009, KUČERA and KROFTA 2009) depends on water supply and air temperatures during the hop vegetation and particularly during the technological maturity of hop cones.

The phases of morphogenesis in general correspond with the results of OLIVEIRA and PAIS $(1988,1990)$ and the SEM observations of SAITO et al. (1995) and HiROSAWA et al. (1995). OliveIRA and PAIS (1988) described the morphological differences between peltate and bulbous trichomes and also found that the number of peltate trichomes decreases with the expansion of the leaves (bracts).

It can thus be concluded with some certainty that the number and volume of peltate glandular trichomes as well as their morphogenesis and consequently accumulation of $\alpha$-acids are greatly influenced by climatic factors.

\section{References}

Anonymous, 1998: Analytica-EBC, Methods of analysis, EBC Analysis Committee, Nurnberg, Germany.

ANONYMOUs, 2006: Analytica - European Brewery Convention 7.4 http://www.european breweryconvention.org/PDF/Analytica-EBC-Contents 2006 + last amendment.pdf

Briggs, D. E., Hough, J. S., Stevens, R., Young, T. W. 1981: Malt and brewing science, 1. Malt and Sweet Worth, Chapman and Hall, London. 
ChAnTER, D. O., 1975: Modifications of the angular transformation. Journal of the Royal Statistical Society. Series C (Applied Statistics) 24, 354-359.

ČEH, B., KAČ, M., KošIR, I. J., ABRAM, V., 2007: Relationship between xanthohumol and polyphenol content in hop leaves and hop cones with regard to water supply and cultivar. International Journal of Molecular Sciences 8, 989-1000.

FORSTER, A., 1987: Conductometric methods for hops and hop products. European Brewery Convention Symposium on Hops, Freising-Weihenstephan, 17-19.

Forster, A., 2001: The quality chain from hops to hop products. Proceedings 48 International Hop Growers Congress, Canterbury, 6-10.

HiLl, T., LEWICKI, P. 2006: Statistics: methods and applications. StatSoft, Inc., Tulsa.

Hirosawa, T., Saito, T., Tanaka, T., Matasushima, H., 1995: SEM observation and HPLC analysis of the accumulation of alpha- and beta- acids in the fresh developing hop (Humulus lupulus L.) peltate glandular trichomes. Journal of Electron Microscopy 44, 145-147.

Kim, E. S., Mahlberger, P. G., 2000: Early development of the secretory cavity of peltate glands in Humulus lupulus L. (Cannabaceae). Molecules and Cells 10, 487-492.

KoŠIR, I., 1996: The chemistry and analytics of hops. Proceedings 33 Hop Seminar, Žalec. Hop Bulletin Supplement 1, 73-83.

KuČERA, J., KROFTA, K., 2009: Mathematical model for prediction of alpha acid contents from meteorological data for 'Saaz' aroma variety. Acta Horticulturae 848, 131-139.

Mozny, M., Tolasz, R., Nekovar, J., Sparks, T., Trnka, M., Zalud, Z., 2009: The impact of climate change on the yield and quality of Saaz hops in Czech Republic. Agricultural and Forest Meteorology 149, 913-919.

OliveIRA, M. M., PAIS, M. S., 1988: Glandular trichomes of Humulus lupulus var. Brewers Gold: Ontogeny and histochemical characterization of the secretion. Nordic Journal of Botany 8, 349-359.

OliveIRA, M. M., PAIS, M. S., 1990: Glandular trichomes of Humulus lupulus var. Brewers Gold (hops): ultrastructural aspects of peltate trichomes. Journal of Submicroscopic Cytology and Pathology 22, 241-248.

Saito, T., Hirosawa, T., Horiuchi, S., Murakami, A., Matsushima, H., 1995: A study of SEM examination on fresh hop (Humulus lupulus L.) peltate glandular trichomes. Journal of Electron Microscopy 44, 39-44.

SREČEc, S., KvaternjaK, I., KaUČIĆ, D., Špoljar, A., Erhatić, R., 2008: Influence of climatic conditions on accumulation of $\alpha$-acids in hop cones. Agriculturae Conspectus Scientificus 73, 161-166.

SugiYama, R., Oda, H., Kurosaki, F., 2006: Two distinct phases of glandular trichome development in hop (Humulus lupulus L.). Plant Biotechnology 23, 493-496.

Wang, G., Tian, L., Aziz, N., Broun, P., Dai, X., He, J., King, A., Zhao, P. X., Dixon, R. A., 2008: Terpene biosynthesis in glandular trichomes of hop. Plant Physiology 148, 1254-1266. 